\title{
Box-Behnken Design for Optimization on Biodiesel Production from Palm Oil and Methyl Acetate using Ultrasound Assisted Interesterification Method
}

\author{
Ansori Ansori' ${ }^{1}$ Mahfud Mahfud ${ }^{1 *}$ \\ 1 Department of Chemical Engineering, Faculty of Industrial Technology and Systems Engineering, Institut Teknologi Sepuluh \\ Nopember, Jalan Raya ITS, 60111 Surabaya, Sukolilo, P.O.B. 1400A, Indonesia \\ * Corresponding author, e-mail: mahfud@chem-eng.its.ac.id
}

Received: 01 December 2020, Accepted: 27 May 2021, Published online: 05 October 2021

\begin{abstract}
Energy demand is currently increasing in line with technological and economic developments, but not accompanied by an increase in energy reserves. So we need another alternative energy that can be renewed, namely biodiesel. Biodiesel has been produced commercially through the transesterification from vegetable oil with methanol using catalyst that produces esters and glycerol. The formation of glycerol which is by-product can reduce its economic value, so it needs to be done the separation process. Therefore, a new route is proposed in this study, namely the interesterification reaction (non-alcoholic route) using methyl acetate as an alkyl group supplier and potassium methoxide catalyst. The superiority of the product produced by the interesterification reaction is biodiesel with triacetin byproducts which have an economical value and can be added to biodiesel formulations because of their solubility so that no side product separation process is needed. To increase the yield of biodiesel and the interesterification rate, the ultrasound method was used in this study. To optimize the factors that affect the interesterification reaction (molar ratio of methyl acetate to oil, catalyst concentration, temperature, and interesterification time), the Box-Behnken design (BBD) is used. Optimal operating conditions to produce the yields of biodiesel of $98.64 \%$ are at molar ratio of methyl acetate to palm oil of 18.74 , catalyst concentration of $1.24 \%$, temperature of $57.84{ }^{\circ} \mathrm{C}$, and interesterification time of 12.69 minutes.
\end{abstract}

Keywords

biodiesel, Box-Behnken design, energy, interesterification, ultrasound

\section{Introduction}

In today's modern era, energy is the most basic requirement of all human activities, especially in the field of technology and economy, both as raw material, fuel, and as an export commodity. Energy consumption continues to increase in line with the rate of economic growth and population growth. Where the energy needs are still largely met by non-renewable energy. Non-renewable energy contributes $86 \%$ of total global energy [1]. Recently, the trend of reducing non-renewable energy has become increasingly visible. This results in the need for the latest innovations that will replace the use of non-renewable energy. One of its innovations is the manufacture of biodiesel, which will replace diesel fuel. Some of the advantages of biodiesel include a renewable energy source that guarantees the continuity of production, is nontoxic, biodegradable, has a high cetane number and low flash point, can be an environmentally friendly alternative fuel, and does not require engine modification $[2,3]$.
Biodiesel fuel is made from vegetable oil, animal fat, and used oil. In general, vegetable oil is more developed because it has advantages over other oils, including vegetable oil which is a natural resource that is available in excess and can be renewed. One of the things that have become the center of attention as a raw material for biodiesel is palm oil. In Indonesia, the growth in the palm oil production sector is very high, where the annual growth rate was greater than $12 \%$ from 1990 to 2005 [4]. Meanwhile, according to Varqa in Palm Oil Analytics [5], Indonesia is in the first position in producing palm oil in the world, amounting to $34,520,000$ tons in 2016. This makes palm oil potential for further processing into renewable energy.

Biodiesel has been produced commercially through the transesterification reaction of vegetable oils with methanol using a catalyst that produces esters and glycerol. The formation of glycerol which is a byproduct of the 
transesterification process has no economic value and the presence of glycerol can be said to be impurities in biodiesel products. So it is necessary to do the separation and washing processes to achieve high purity biodiesel products $[6,7]$. However, the refining process requires high capital, operation, and energy costs in the industrial process. In addition, in biodiesel production, glycerol can be produced up to $10 \%$ (based on the mass of oil) of the biodiesel obtained. So that the amount of glycerol exceeds the acceptable limit on the market and results in a low selling price [8]. Therefore, a new, more effective route is proposed in this study, namely the interesterification reaction (non-alcoholic route) using methyl acetate as an alkyl group supply and by adding a catalyst. The use of methyl acetate in place of methanol will produce triacetin as a byproduct of glycerol substitute. Triacetin is a byproduct that has more economic value and can be added to biodiesel formulations because of its mutually soluble nature. Due to the good solubility of triacetin on biodiesel, its presence of up to $10 \%$ by weight still produces biodiesel fuel that meets the quality standards of ASTM D6451 and EN 14214 and also the mixture does not have a bad effect on the final quality of the fuel and the combustion process in the engine $[9,10]$. The addition of triacetin to biodiesel is also expected to reduce the pour point value of biodiesel so that it can withstand extreme cold weather [10]. The superiority of the biodiesel product produced by the interesterification reaction is biodiesel with triacetin as a byproduct which can be used as a fuel additive to reduce engine knocking so that no side product separation process is required.

In producing biodiesel, there are many methods used to increase the reaction rate as well as the biodiesel yield. Among them by using a catalyst [11], without a catalyst (supercritical conditions) [12-14], enzymes [15], microwave [16], ultrasound [17, 18], and others. Enzymatic and supercritical methods have been widely used for biodiesel production using interesterification reactions. However, both methods require high production costs [12, 19]. In order to reduce operating costs and at lower reaction conditions, the reaction is carried out by a chemical interesterification method using a catalyst of potassium methoxide. The use of potassium methoxide due to its nearly waterfree nature results in higher yields, lower refining costs, and more consistent biodiesel quality. However, there is a difficulty in this interesterification reaction, where oil and methyl acetate do not mix with each other. So that in this interesterification reaction the ultrasound method is used to assist in mixing the reactants properly and can increase the yield of biodiesel. The utilization of ultrasonic waves will help emulsify immiscible reactants using microturbulence [7]. The ultrasound method can also increase the mass transfer and interesterification rate so that the interesterification reaction occurs more easily in a shorter time. In addition, ultrasound can also improve reaction kinetics, especially in slow reactions [18]. Ultrasonic waves will provide enormous energy so that it will increase the reaction speed due to the cavitation effect. Ultrasound can be applied in various categories of reactions such as catalytic reactions, enzyme-catalytic reactions, ion-exchange reactions, and double-phase reactions [20], as well as interesterification reactions, are also included.

In optimizing the operating parameters, a statistical approach is used, namely the response surface method (RSM). RSM is used to reduce the number of experimental trials required and also to evaluate multiple factors and their interactions. So that the experimental process is faster and authentic [21]. The Box-Behnken design (BBD) is one of the many types of designs available at RSM which has been widely used to optimize biodiesel manufacturing. This is because BBD can predict, is more effective in parameter optimization, and the least number of trials is required than other designs. In addition, BBD also provides higher efficiency in terms of the ratio between the number of coefficients on the model and the total number of trials compared to the central composite design (CCD) [22]. Medeiros et al. [18] have conducted research on the interesterification reaction of cotton oil and methyl acetate. They performed an optimization process using ultrasound and BBD to determine the behavior of process variables in the interesterification reaction. Where the optimal conditions obtained occurred at a catalyst concentration of $1.17 \%$, the molar ratio of the reactants $1: 14.87 \%, 67.3 \%$ of the vibration pulses, and $67.64 \%$ of the ultrasound probe amplitude, with a conversion obtained of $98.12 \%$. And, the use of ultrasound provides a $14 \%$ increase in triglyceride conversion compared to conventional methods. Meanwhile, Akkarawatkhoosith et al. [23] has conducted research on the interesterification reaction of palm oil with ethyl acetate in a small-scale fixed-bed reactor. Optimization was carried out using BBD, where the yield obtained at optimal conditions was $99 \%$ (at $113{ }^{\circ} \mathrm{C}, 16.7: 1$ molar ratio, and total mass flow rate of $5.4 \times 10^{-4} \mathrm{~kg} / \mathrm{h}$ ) for 72 hours of continuous operation. In addition, Kashyap et al. [24] has also optimized the interesterification reaction of Karanja oil using ultrasound and analysis of RSM. Where 
the maximum yield of methyl ester obtained is $91.56 \%$, at conditions of 1:9 molar ratio of reactants, $1 \%$ catalyst concentration, and $60 \%$ duty cycle for $35 \mathrm{~min}$. They also reported that increasing the temperature would increase the biodiesel yield and the use of ultrasound could decrease the need for feedstock.

Therefore, in this study, the Box-Behnken design (BBD) was applied to optimize and analyze the effects of interesterification parameters (reactant molar ratio, catalyst concentration, temperature and interesterification time) on biodiesel production using the ultrasound-assisted interesterification method.

\section{Materials and method}

\subsection{Materials and catalyst}

The palm oil used as a raw material in this study is the Bimoli brand palm oil obtained from supermarkets. Meanwhile, all chemicals were of analytical grade. The chemicals needed for this research were methyl acetate in the form of pure analysis (Merck KGaA, $99 \%$ ) obtained from a chemical supplier UD. Sumber Ilmiah Persada in Surabaya. Methanol is the form of pure analysis (Merck KGaA, purity $99.9 \%$ ) obtained from PT. Kurniajaya Multisentosa. Whereas potassium methoxide $99 \%$ (Zhishang Chem) obtained from Shandong Zhi Shang Chemical Co. Ltd., and phosphoric acid (ortho, $85 \%$ ) and were used as received.

\subsection{Equipmental apparatus for biodiesel production using ultrasound-assisted interesterification}

The main equipment for the interesterification process is an ultrasonic cleaning bath and a reflux device. The ultrasonic cleaning bath used is KRISBOW model KW1801033, has a voltage of $240 \mathrm{~V} / 50 \mathrm{~Hz}$, a power of $100 \mathrm{~W}$, a maximum frequency of $40 \mathrm{kHz}$, a tank capacity of $2.8 \mathrm{~L}$ for heat sources in the interesterification process. Meanwhile, the reflux device consists of a $1000 \mathrm{~mL}$ three-neck Pyrex round bottom flask, a $40 \mathrm{~cm}$ reflux condenser, and a thermocouple to determine the temperature of the interesterification reaction. The interesterification reaction was carried out by adding palm oil and methyl acetate in a triple neck flask with the molar ratio of the reactants as stated in the experimental variables and mixed. The mixture is heated to the required temperature using a mantle heater. After constant temperature, a mixture of potassium methoxide and methanol is added to the flask according to variable and transfer the flask to the ultrasound-assisted interesterification device (Fig. 1), to undergo the interesterification

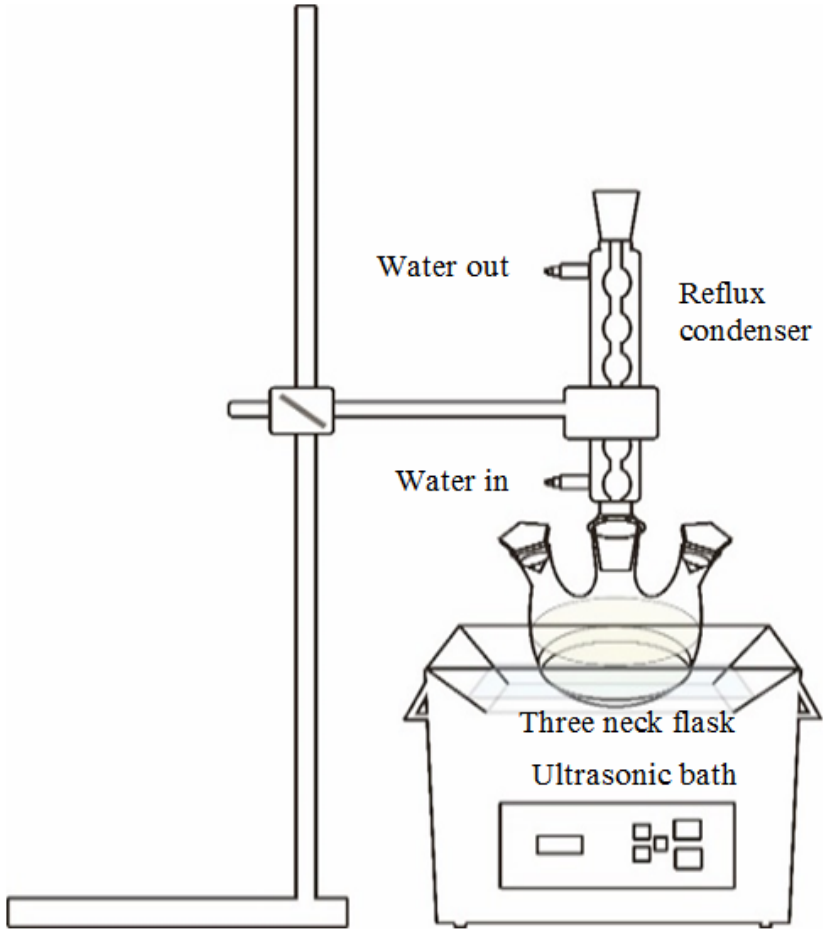

Fig. 1 Equipmental apparatus for biodiesel production using ultrasound-assisted interesterification

process according to the specified reaction time. After the reaction is complete, $0.1 \mathrm{~mL}$ of phosphoric acid is added to stop the reaction. Then the product mixture is transferred to a separating funnel and washed with $20 \mathrm{~mL}$ warm water to remove impurities such as residual methyl acetate and catalyst from the product. The funnel is stirred with shock and left until it forms two layers. The top layer is transferred to a beaker, then heated by an oven at $110^{\circ} \mathrm{C}$ to separate the volatile substances from the product. Furthermore, an analysis of the products obtained is carried out.

\subsection{Box-Behnken design for optimization of biodiesel production}

To optimize the yield of biodiesel production, statistical techniques have been used to monitor and show the optimum conditions for the interesterification process, namely the response surface methodology (RSM). This RSM uses quantitative data from experiments to determine linear regression models and to optimize responses that are influenced by several factors. The advantages of this RSM method include obtaining factor levels that make the experiment optimal, minimizing the number of experimental required, and optimizing using the resulting response equation prediction, so as to save experimental costs. RSM aims to assist researchers in improvising to get optimum results precisely and efficiently $[21,25]$. 
In this study, a three-level, four-factors, Box-Behnken Design (BBD) was applied to generate a total of 29 experiments for the optimization of ultrasound-assisted interesterification parameters and to evaluate the combined effects of three factors. The factors include the molar ratio of methyl acetate to palm oil (A), concentration of catalyst (B), temperature $(\mathrm{C})$, and interesterification time (D). Each factor is varied within the range of: A $(5: 1-25: 1 \mathrm{~mol} / \mathrm{mol}), \mathrm{B}(0.5-1.5 \% \mathrm{wt}), \mathrm{C}\left(35-65^{\circ} \mathrm{C}\right.$, D (5-35 min) as shown in Table 1. For the statistical dissect, Design-Expert ${ }^{\circledR}$ software version 11.1.0.1 (Stat-Ease Inc., Minneapolis, MN, USA) was applied to model the data and to assume the experimental design.

Analysis of regression was carried out for experimental data and entered into a quadratic model (second-order model), such as the following Eq. (1) [25]:

$$
\begin{aligned}
& Y=\beta_{0}+\sum_{i=1}^{k} \beta_{i} X_{i}+\sum_{i=1}^{k} \beta_{i i} X_{i}^{2} \\
& +\sum_{i=1}^{k-1} \sum_{j=i+1}^{k} \beta_{i j} X_{i} X_{j},
\end{aligned}
$$

where $Y$ is the response/ dependent parameter; $\beta_{0}, \beta_{i}, \beta_{i i}$, and $\beta_{i j}$ are regression coefficients for an intercept, linear, quadratic, and interaction; $\mathrm{k}$ is the number of parameters used; $X_{i}$ and $X_{j}$ are factors. The quality of the model used is supported by several response values, including $p$-value, $\mathrm{R}^{2}$, adeq precision, and lack of fit.

\section{Results and discussion}

\subsection{Checking of the fitted models and statistical analysis} In optimization for the manufacture of biodiesel using the ultrasound-assisted interesterification (UAI) method with Response Surface Methodology, four factors are used, namely the molar ratio of methyl acetate to oil (A), catalyst concentration (B), temperature (C), and interesterification time (D). This optimization uses the Box-Behnken Design (BBD) repeating the center point 5 times and was found to be sufficient to calculate the coefficient of the second-order polynomial regression model for four variables. After entering each factor value in the Design-Expert ${ }^{\circledR}$ software version 11.1.0.1 (Stat-Ease Inc., Minneapolis,
MN, USA) by selecting BBD, 29 experimental designs were obtained to obtain the optimum biodiesel yield using the UAI method which can be seen in Table 2. In addition, Table 2 shows the actual and predicted yield of biodiesel obtained by the ultrasound assisted interesterification (UAI) method [22, 24, 26]. Furthermore, an equation is obtained that can be used to predict the biodiesel yield for each given variable.

Based on the experimental design that has been carried out, the biodiesel yield equation can be seen in the quadratic model equation as follows Eq. (2):

$$
\begin{aligned}
& \text { Yield }(\%)=-78.446+4.434 * \mathrm{~A}+30.005 * \mathrm{~B} \\
& +3.391 * \mathrm{C}+1.162 * \mathrm{D}-0.162 * \mathrm{AB}+0.020 * \mathrm{AC} \\
& -0.004 * \mathrm{AD}+0.647 * \mathrm{BC}+0.745 * \mathrm{BD} \\
& -0.021 * \mathrm{CD}-0.123 * \mathrm{~A}^{2}-30.017 * \mathrm{~B}^{2} \\
& -0.036 * \mathrm{C}^{2}-0.023 * \mathrm{D}^{2} .
\end{aligned}
$$

In the BBD methods, a summary of the statistical model is obtained (Table 3). Based on Table 3, it is shown that the quadratic (second-order) model is the most recommended of the other models. This is because the p-value of model is not more than 0.05 , the difference in values between the predicted $\mathrm{R}^{2}$ and adjusted $\mathrm{R}^{2}$ is not more than 0.2 , and $\mathrm{R}^{2}>0.9$. In addition, analysis of variance (ANOVA) was carried out to identify significant factorss and interactions that affect biodiesel yield. The results of ANOVA analysis can be seen in Table 4. An significant factor affecting biodiesel yield is indicated by a p-value of less than $0.05[6,27]$. Based on Table 4, it can be seen that the quadratic model has an F-value of 15.5362 which implies that this model is significant. There is only a less than $0.01 \%$ chance that this F-value could occur due to noise. A p-value of less than 0.05 indicates a significant model term. Meanwhile, the lack of fit is applied to measure the adequacy of the model. Lack of fit has a p-value $>0.05$ which explains that the lack of fit is insignificant. The insignificant lack of fit indicates that the model is logical and valid [27, 28].

In this case, the factors, namely the mole ratio of methyl acetate to oil (A), catalyst concentration (B), and

Table 1 Factors used for optimization of biodiesel production with Box-Behnken design (BBD)

\begin{tabular}{lcccc}
\hline \multirow{2}{*}{ Factors } & Units & \multicolumn{2}{c}{ Levels } \\
\cline { 3 - 5 } & & Low & Middle & High \\
\hline A-Ratio methyl acetate to palm oil & $\mathrm{mol} / \mathrm{mol}$ & $5: 1$ & $15: 1$ & $25: 1$ \\
B-Catalyst concentration & $\% \mathrm{wt}$ & 0.5 & 1 & 50 \\
C-Temperature & ${ }^{\circ} \mathrm{C}$ & 35 & 20 & 65 \\
D-Interesterification time & $\min$ & 5 & 35 \\
\hline
\end{tabular}


Table 2 Results and experimental designs on biodiesel production using ultrasound-assisted interesterification (UAI) with Box-Behnken design (BBD)

\begin{tabular}{|c|c|c|c|c|c|c|}
\hline \multirow{2}{*}{$\begin{array}{l}\text { Methyl acetate to oil } \\
\text { molar ratio (mol) }\end{array}$} & \multirow{2}{*}{$\begin{array}{c}\text { Catalyst } \\
\text { concentration }(\% \mathrm{wt})\end{array}$} & \multirow{2}{*}{ Temperature $\left({ }^{\circ} \mathrm{C}\right)$} & \multirow{2}{*}{$\begin{array}{l}\text { Interesterification } \\
\text { time (min) }\end{array}$} & \multicolumn{3}{|c|}{ Yield (\%) } \\
\hline & & & & Actual & Predicted & Residual \\
\hline 5 & 1.5 & 50 & 20 & 60.7568 & 64.5751 & -3.8183 \\
\hline 5 & 0.5 & 50 & 20 & 49.3514 & 48.1807 & 1.1707 \\
\hline 5 & 1 & 65 & 20 & 58.2703 & 57.1384 & 1.1319 \\
\hline 5 & 1 & 35 & 20 & 59.2432 & 54.3095 & 4.9337 \\
\hline 5 & 1 & 50 & 5 & 53.7297 & 59.7891 & -6.0594 \\
\hline 5 & 1 & 50 & 35 & 60.4324 & 57.7910 & 2.6414 \\
\hline 15 & 1 & 65 & 35 & 77.2432 & 76.3789 & 0.8643 \\
\hline 15 & 1 & 50 & 20 & 89.8378 & 91.4703 & -1.6325 \\
\hline 15 & 1 & 50 & 20 & 86.2703 & 91.4703 & -5.2000 \\
\hline 15 & 1 & 35 & 5 & 67.0811 & 70.6291 & -3.5480 \\
\hline 15 & 1 & 50 & 20 & 92.4865 & 91.4703 & 1.0162 \\
\hline 15 & 1 & 50 & 20 & 95.2973 & 91.4703 & 3.8270 \\
\hline 15 & 1 & 50 & 20 & 93.4595 & 91.4703 & 1.9892 \\
\hline 15 & 0.5 & 65 & 20 & 68.3243 & 68.0253 & 0.2990 \\
\hline 15 & 1.5 & 50 & 35 & 90.0541 & 90.2645 & -0.2104 \\
\hline 15 & 0.5 & 50 & 5 & 81.5135 & 78.6519 & 2.8616 \\
\hline 15 & 0.5 & 50 & 35 & 58.2162 & 64.3236 & -6.1074 \\
\hline 15 & 1.5 & 35 & 20 & 73.6216 & 73.8881 & -0.2665 \\
\hline 15 & 1 & 65 & 5 & 89.5676 & 88.9715 & 0.5961 \\
\hline 15 & 1.5 & 65 & 20 & 91.8919 & 92.5008 & -0.6089 \\
\hline 15 & 1.5 & 50 & 5 & 91.0151 & 82.2566 & 8.7585 \\
\hline 15 & 1 & 35 & 35 & 73.6216 & 76.9014 & -3.2798 \\
\hline 15 & 0.5 & 35 & 20 & 69.4595 & 68.8181 & 0.6414 \\
\hline 25 & 1 & 65 & 20 & 91.6216 & 93.9041 & -2.2825 \\
\hline 25 & 1 & 35 & 20 & 80.4324 & 78.9131 & 1.5193 \\
\hline 25 & 1 & 50 & 35 & 93.4054 & 87.3135 & 6.0919 \\
\hline 25 & 1.5 & 50 & 20 & 89.7838 & 93.6382 & -3.8544 \\
\hline 25 & 1 & 50 & 5 & 89.0270 & 91.6359 & -2.6089 \\
\hline 25 & 0.5 & 50 & 20 & 81.6216 & 80.4870 & 1.1346 \\
\hline
\end{tabular}

Table 3 Model summary statistics for the interesterification reaction using BBD

\begin{tabular}{|c|c|c|c|c|c|c|}
\hline Source & Sequential p-value & Lack of Fit p-value & $\mathrm{R}^{2}$ & Adjusted $\mathrm{R}^{2}$ & Predicted $\mathrm{R}^{2}$ & \\
\hline Linear & $3.19 \mathrm{E}-05$ & 0.0279 & 0.6478 & 0.5891 & 0.5320 & \\
\hline $2 \mathrm{FI}$ & 0.7122 & 0.0213 & 0.7081 & 0.5460 & 0.4124 & \\
\hline Quadratic & 0.0001 & 0.2027 & 0.9395 & 0.8791 & 0.6875 & Suggested \\
\hline Cubic & 0.1283 & 0.4022 & 0.9866 & 0.9372 & 0.2781 & Aliased \\
\hline
\end{tabular}

temperature (C) show important values for all factors by giving a significant effect on biodiesel yield ( $p$-value $<0.05$ ), while the interesterification time (D) did not have a significant effect $(p>0.05)$. In addition, the quadratic model can evaluate and analyze the interaction of each parameter. Where the interaction between molar ratio of methyl acetate to oil and catalyst concentration (AB), molar ratio of methyl acetate to oil and temperature (AC), molar ratio of methyl acetate to oil and interesterification time (AD), catalyst concentration and temperature (BC), and temperature and interesterification time (CD), which shows the insignificant effect ( $p>0.05)$, which means that the factors are less influential for the biodiesel manufacturing process. However, only the interaction between catalyst concentration and interesterification time (BD) showed a significant effect $(\mathrm{p}<0.05)$. While the quadratic parameters, which are the molar ratio of methyl acetate to oil $\left(\mathrm{A}^{2}\right)$, catalyst concentration $\left(\mathrm{B}^{2}\right)$, temperature $\left(\mathrm{C}^{2}\right)$, and interesterification 
Table 4 ANOVA of the quadratic model to identify significant factors using BBD

\begin{tabular}{|c|c|c|c|c|c|c|}
\hline Source of variations & Sum of squares & $\mathrm{df}$ & Mean square & F-value & p-value & \\
\hline Model & 5434.8748 & 14 & 388.2053 & 15.5362 & 0.0001 & * \\
\hline A: Methyl acetate to oil molar ratio & 2824.6463 & 1 & 2824.6463 & 113.0441 & 0.0001 & $*$ \\
\hline B: Catalyst concentration & 654.7069 & 1 & 654.7069 & 26.2018 & 0.0002 & $*$ \\
\hline C: Temperature & 238.1599 & 1 & 238.1598 & 9.5313 & 0.0080 & $*$ \\
\hline D: Interesterification time & 29.9603 & 1 & 29.9603 & 1.1990 & 0.2920 & $* *$ \\
\hline $\mathrm{A}^{2}$ & 972.7286 & 1 & 972.7286 & 38.9292 & 0.0001 & $*$ \\
\hline $\mathrm{B}^{2}$ & 365.2674 & 1 & 365.2674 & 14.6182 & 0.0019 & $*$ \\
\hline $\mathrm{C}^{2}$ & 431.7027 & 1 & 431.7027 & 17.2770 & 0.0010 & * \\
\hline $\mathrm{D}^{2}$ & 168.1845 & 1 & 168.1845 & 6.7309 & 0.0212 & $*$ \\
\hline $\mathrm{AB}$ & 2.6296 & 1 & 2.6296 & 0.1052 & 0.7504 & $* *$ \\
\hline $\mathrm{AC}$ & 36.9792 & 1 & 36.9792 & 1.4799 & 0.2439 & $* *$ \\
\hline $\mathrm{AD}$ & 1.3506 & 1 & 1.3506 & 0.0541 & 0.8195 & $* *$ \\
\hline $\mathrm{BC}$ & 94.1434 & 1 & 94.1434 & 3.7677 & 0.0727 & $* *$ \\
\hline $\mathrm{BD}$ & 124.7276 & 1 & 124.7276 & 4.9917 & 0.0423 & $*$ \\
\hline $\mathrm{CD}$ & 88.9711 & 1 & 88.9711 & 3.5607 & 0.0801 & $* *$ \\
\hline Residual & 349.8195 & 14 & 24.9871 & & & \\
\hline Lack of fit & 300.4790 & 10 & 30.0479 & 2.4360 & 0.2027 & $* *$ \\
\hline Pure error & 49.3406 & 4 & 12.3351 & & & \\
\hline Cor total & 5784.6944 & 28 & & & & \\
\hline
\end{tabular}

* = significant

$* *=$ not significant

time $\left(\mathrm{D}^{2}\right)$, all have a significant effect on biodiesel yield because they have a $\mathrm{p}$-value $<0.05$. This shows that $\mathrm{A}, \mathrm{B}$, $\mathrm{C}, \mathrm{BD}, \mathrm{A}^{2}, \mathrm{~B}^{2}, \mathrm{C}^{2}$, and $\mathrm{D}^{2}$ are the main factors in the interesterification process that affect biodiesel yield using ultrasound-assisted interesterification (UAI) method.

So that in the UAI method, optimization will result in the most influential interaction between concentration of catalyst and interesterification time. The UAI method is better designed using a quadratic model because all quadratic parameters have a significant or influential effect. This shows that the model is accurate enough to predict any combination of independent factors in the range of this study and can become a reference if research is carried out on making biodiesel with the interesterification process using the ultrasound-assisted interesterification method.

The statistical model in Table 5 can be used to evaluate the actual data from the parameters used. Model coefficients are represented by constants, linear coefficients for independent variables, interactive term coefficients, and squared term coefficients. Then, the coefficient of determination $\left(\mathrm{R}^{2}\right)$, adjusted coefficient of determination (adj$\mathrm{R}^{2}$ ), predicted coefficient of determination (pred- $\mathrm{R}^{2}$ ), and adeq precision that can be used to evaluate the fit of the model. Usually by maximizing the adjusted $\mathrm{R}^{2}$ and the predicted $\mathrm{R}^{2}$; this model is said to be adequate when the value is $\mathrm{p}<0.05$; lack of fit $(\mathrm{p}>0.05)$; and $\mathrm{R}^{2}>0.9[24,27]$.
Table 5 Summary and fitting statistics from ANOVA

\begin{tabular}{ll}
\hline Fit statistics & Result \\
\hline Mean & 77.8151 \\
Coefficient of variance $(\mathrm{CV}) \%$ & 6.4238 \\
$\mathrm{R}^{2}$ & 0.9395 \\
Adjusted-R & \\
Predicted-R & \\
Adeq precision & 0.8791 \\
\hline
\end{tabular}

The model obtained has an $\mathrm{R}^{2}$ value of 0.9395 , this indicates that the proposed model explains $93.95 \%$ of the variability in responses (experimental values). A high $\mathrm{R}^{2}$ value indicates a good correlation between experimental and predictive response values so that the model's reliability is high in predicting biodiesel yield. Meanwhile, the predicted value of $\mathrm{R}^{2}$, which is 0.6875 , is within reasonable terms with an adjusted $\mathrm{R}^{2}$ value of 0.8791 , where the value does not have a difference of more than 0.2 , which means that the model is suitable. In addition, an adeq precision $>4$ indicating a sufficient signal and model can be used to navigate the next design. Adeq precision value is adequate (12.7184), which means that the model can be used for optimization $[24,26]$. This shows that the model is good and can improve the relationship between process parameters in response so that the optimization model can be applied. 


\subsection{Interaction between parameters and graphical interpretation of RSM}

In this study, a contour plot was used to investigate the main effect and interaction of several factors on the response in the form of biodiesel yield made from the interesterification process of palm oil with potassium methoxide catalyst using the ultrasound-assisted interesterification method. A contour plot is a graphical representation of the regression equation showing two factors, while the other factors are maintained at a constant level. Where this contour plot is obtained from the regression model in the quadratic model described by Eq. (2). This plot presents the effects of the molar ratio of methyl acetate to oil (A), catalyst concentration (B), temperature (C), interesterification time (D) which are presented in Fig. 2.

\subsubsection{Effects of ratio molar of methyl acetate to oil and concentration of catalyst}

In Fig. 2(a), when a 3-D response surface plot is developed to show the effect of the interaction between the molar ratio of methyl acetate to oil $(5: 1-25: 1)$ and the concentration of catalyst (0.5-1.5 wt $\%)$ while maintaining the temperature at $50{ }^{\circ} \mathrm{C}$ and the interesterification time for 20 min. Based on Fig. 2(a), it can be explained that the higher the mole ratio of methyl acetate to oil, the yield tends to increase. This is because the higher the ratio of methyl acetate to oil will encourage the interesterification reaction towards the product and also the more frequent contact that occurs between methyl acetate and oil so that it will result in an increase in the conversion of triglycerides to biodiesel. This is in accordance with research conducted by Ribeiro et al. [29]. They explained that the higher the molar ratio between methyl acetate and oil, the higher the FAME and triacetin levels. Furthermore, the oil to methyl acetate molar ratio of 1:20 was chosen as the best condition to continue investigating the reaction parameters. Likewise, for the catalyst concentration, it also provides an increase in biodiesel yield when the use of the catalyst concentration increases from $0.5-1.5 \mathrm{wt} \%$. Where the optimal conditions were obtained at an increase in the catalyst concentration of $1.24 \%$. At a catalyst concentration of $0.5 \%$, the yield is still low because the triglyceride conversion is not perfect. However, the use of a catalyst that exceeds the optimum does not provide a significant increase but can reduce the yield of biodiesel. This is in accordance with research conducted by Maddikeri et al. [17], they explained that the concentration of the catalyst (potassium methoxide) which is at $1 \%$ will increase the reaction conversion by $90 \%$, in contrast to a smaller concentration $(0.5 \%)$ will cause imperfect conversion of triglycerides to methyl esters so that the yield that will be produced is also small. Whereas, a further increase in the catalyst concentration from 1 to $1.25 \%$ did not show a significant increase in the biodiesel yield. This is possible because the use of an excess of alkaline homogeneous catalysts can absorb the product which will result in a decrease in product yield [30]. Meanwhile, according to El-Gendy et al. [31], high catalyst concentrations can cause resistance to mass transfer, slow down the reaction rate, and ultimately reduce biodiesel conversion. The interaction between the molar ratio of the reactants and the catalyst concentration has a significant effect on the increase in the yield of biodiesel obtained. This can be seen clearly in Fig. 2(a), where when the molar ratio of the reactants is $15: 1$ and the catalyst concentration is $1 \%$, it has shown an increase in biodiesel yield up to $90 \%$.

\subsubsection{Effects of ratio molar of methyl acetate to oil and temperature}

The effect of the interaction between the molar ratio of methyl acetate to oil (5:1-25:1) and temperature $\left(35-65^{\circ} \mathrm{C}\right)$ varies while maintaining the $1 \mathrm{wt} \%$ catalyst concentration and the 20 min interesterification time shown in the 3-D response surface plot (Fig. 2(b)). The interaction between the molar ratio of the reactants and the reaction temperature has a big influence on optimizing the biodiesel yield. Where the more molar ratio of the reactants is used, the yield of biodiesel will be increased. However, increasing the molar ratio of the reactants beyond optimal conditions did not increase the yield of biodiesel significantly. This can be attributed to the fact that the use of a higher molar ratio results in a dilute product that triggers a reverse reaction which reduces biodiesel conversion [14]. In addition, unreacted methyl acetate can limit the equilibrium of the reaction which results in a low ester yield [32]. This is in accordance with research conducted by Maddikeri et al. [17], who reported the interesterification reaction of used cooking oil with a catalyst of potassium methoxide with ultrasound assistance. Where the higher the molar ratio of oil to methyl acetate causes a higher conversion of oil to biodiesel and 1:12 is the optimal molar ratio of the reactants with $90 \%$ biodiesel yield. However, a further increase does not provide an increase in triglyceride conversion. In addition, the temperature increase also increases the yield of biodiesel obtained. This is because the higher the reaction temperature will result in better contact with the reactants 


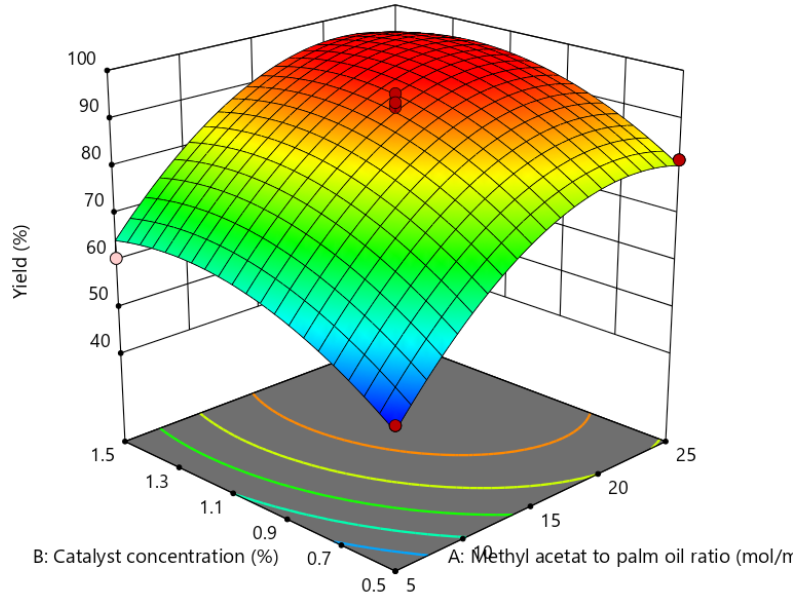

(a)

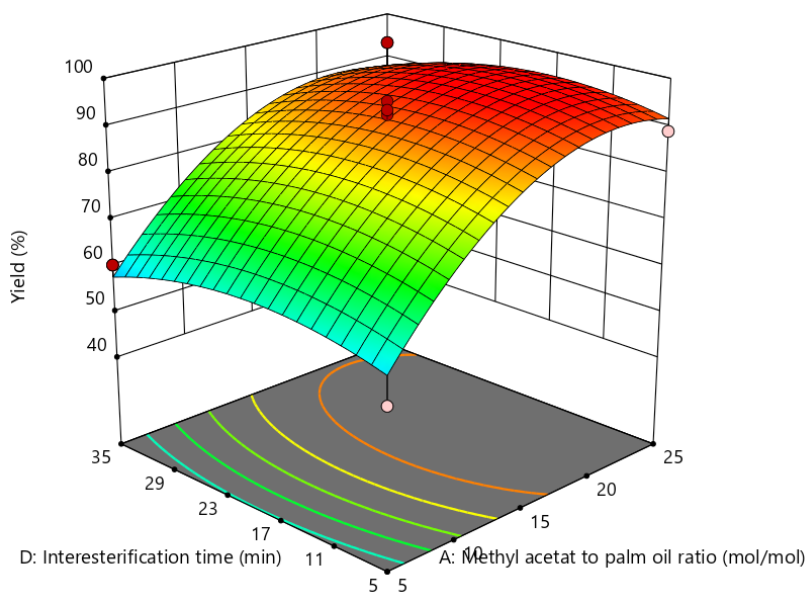

(c)

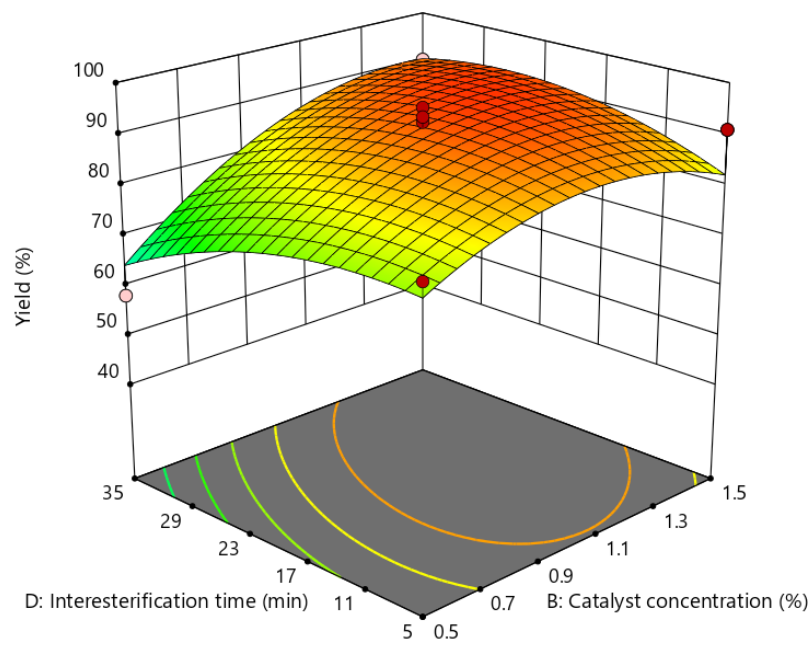

(e)

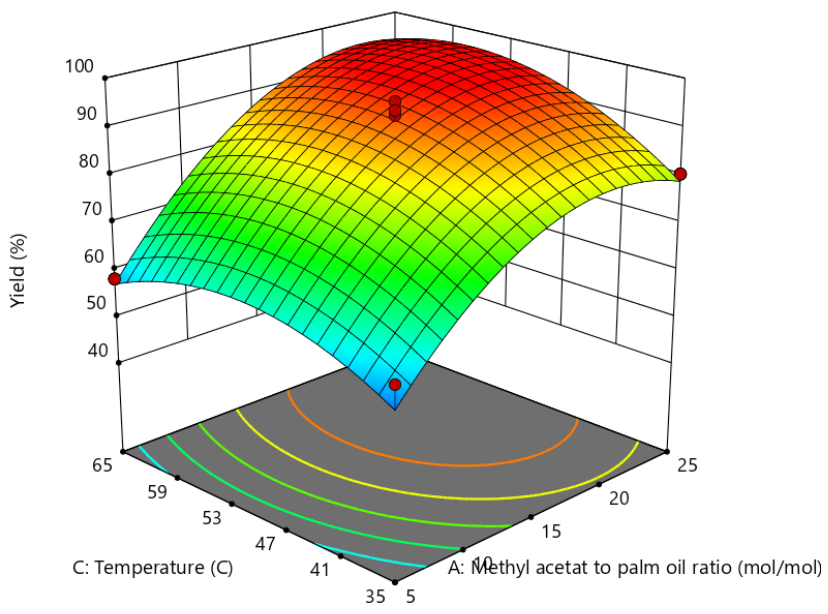

(b)

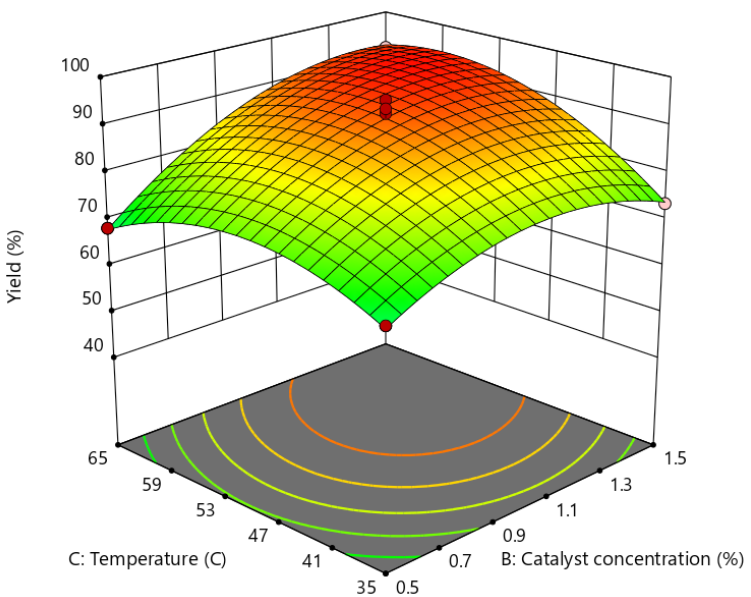

(d)

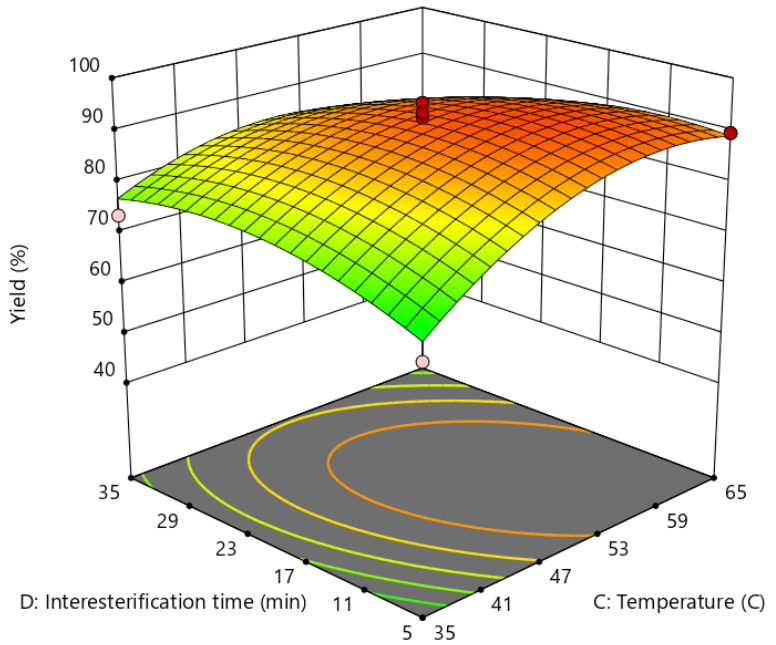

(f)

Fig. 2 3-D contour plot on biodiesel production using the ultrasound-assisted interesterification method with Box-Behnken design showing the effect of the interaction between (a) molar ratio of methyl acetate to oil and concentration of catalyst, (b) molar ratio of methyl acetate to oil and temperature, (c) molar ratio of methyl acetate to oil and interesterification time, (d) catalyst concentration and temperature, (e) catalyst concentration and interesterification time, (f) temperature and interesterification time. 
so that the reaction speed will increase and the conversion of oil to biodiesel will also increase. This is consistent with research reported by Maddikeri et al. [17], which explains that the best operating temperature is $50{ }^{\circ} \mathrm{C}$ for the interesterification reaction of oil and methyl acetate using ultrasonic waves. However, too high a temperature does not give a high yield increase but can reduce the yield obtained. This is due to the presence of missing methyl acetate due to evaporation (boiling point of methyl acetate $57.1^{\circ} \mathrm{C}$ ) which filled the reflux condenser. This evaporation causes the contact that occurs between the methyl acetate and the oil to decrease, thereby reducing the reaction speed and will cause a decrease in the conversion of reactants to biodiesel products. The reactants that have been converted into biodiesel and triacetin will undergo further reactions as the pressure increases and the temperature increases [16]. In addition, higher operating temperatures lead to lower levels of cavitation effects [17].

\subsubsection{Effects of ratio molar of methyl acetate to oil and interesterification time}

A slight difference is shown in Fig. 2(c), which shows the 3-D plot applied to determine the effect of the interaction of the molar ratio of methyl acetate to oil (5:1-15:1) and the interesterification time (5-35 min), during which the catalyst concentration is maintained at $1 \% \mathrm{wt}$ and reaction temperature at $55^{\circ} \mathrm{C}$. Where the increase in interesterification time does not make a significant change in the biodiesel produced. Meanwhile, the use of a higher molar ratio of reactants will also produce higher biodiesel. Where an increase in the molar ratio of the reactants to $15: 1$ gives biodiesel yield of $90 \%$ for a reaction time of 5-30 min. According to Medeiros et al. [18], the interesterification reaction is fast with a $50 \%$ conversion for 1 minute of reaction. However, the use of too much reactant molar ratio (18.74:1) does not give a high increase in biodiesel yield, it can even reduce biodiesel yield over a long reaction time (30-35 min). Based on Fig. 2(c), the biodiesel yield obtained between the interesterification time of 5 to $30 \mathrm{~min}$ tends to be constant, especially at the reactant molar ratio of $15: 1$ to $25: 1$. This shows that biodiesel production has almost reached an unfavorable time in increasing the yield value. This is supported by the theory which states that the interesterification reaction is a reversible reaction. So that when it reaches equilibrium, the reaction will shift to the left (towards the reactants) which will reduce the resulting product, because of the concentration of reactants decreases which causes the reaction speed to be smaller.
Meanwhile, if the interesterification process is carried out in a shorter time, it is feared that the reaction will be less than perfect and perhaps the production of monoglycerides and diglycerides will increase so that the yield obtained will decrease [11]. Subhedar and Gogate [15], have conducted an interesterification study using ultrasound assistance with a lower need for methyl acetate as optimal, and also a higher yield was obtained within 3 hours of the reaction time of $96.1 \%$. Ultrasound can accelerate organic synthesis in a relatively shorter time compared to conventional heating due to increased reaction rates $[17,33]$.

\subsubsection{Effects of concentration of catalyst and temperature}

Meanwhile, Fig. 2(d) shows the effect of catalyst concentration and temperature on a molar ratio of 15: 1 and an interesterification time of $20 \mathrm{~min}$. Based on Fig. 2(d), increasing the catalyst concentration and reaction temperature will simultaneously cause more biodiesel to be produced. According to Kashyap et al. [33], higher temperatures significantly reduce the surface tension and viscosity of fluids thus making cavitation easier. High temperatures can also increase the presence of liquid vapor during the compression cycle which affects the cavitation activity. The interaction between catalyst concentration and reaction temperature on biodiesel yield does not have a significant effect. However, the linear or quadratic factors of the catalyst concentration and reaction temperature have a significant effect as shown in Table 3. The presence of a catalyst in a certain concentration will reduce the activation energy so that it will accelerate the reaction rate. In addition, Fig. 2(d) also explains that the catalyst concentration range of $1-1.5 \%$ wt gives biodiesel yield above $90 \%$ in the reaction temperature range between $47-65{ }^{\circ} \mathrm{C}$. This is in accordance with research reported by Kashyap et al. [33] which explains that the best operating temperature of $50{ }^{\circ} \mathrm{C}$ and a catalyst concentration of $1 \%$ has produced $91 \%$ biodiesel for interesterification reactions using the help of ultrasonic waves. Therefore, the optimum conditions in this study were obtained at a catalyst concentration of $1.24 \% \mathrm{wt}$ and a reaction temperature of $57.84{ }^{\circ} \mathrm{C}$.

\subsubsection{Effects of concentration of catalyst and interesterification time}

In Fig. 2(e), the increase in catalyst concentration has more effect than the interesterification time on the amount of biodiesel produced. In the absence of a catalyst, the interesterification reaction will be very slow so that it takes longer to 
reach equilibrium. So that the presence of a catalyst and the use of ultrasound can reduce the interesterification time. With the presence of a catalyst and ultrasound, the interesterification reaction will take place quickly, where 1 minute of reaction can convert oil into biodiesel up to $50 \%$ with a catalyst concentration of $1.17 \%$ [18]. Meanwhile, Postaue et al. [13] conducted research on interesterification in the absence of a catalyst under supercritical conditions. They reported that the highest yield (below $60 \%$ ) was obtained during 45 minutes of the interesterification reaction. In addition, the interaction between catalyst concentration and interesterification time on biodiesel yield has a significant effect, where the p-value is less than $5 \%$. Where the biodiesel yield above $90 \%$ is obtained at a catalyst concentration of $1-1.5 \% \mathrm{wt}$ and the interesterification time is $10-30 \mathrm{~min}$. Therefore, the optimum conditions were obtained at a catalyst concentration of $1.24 \% \mathrm{wt}$ for $12.69 \mathrm{~min}$ of interesterification time. According to the Arrhenius law regarding the effect of reaction time, if there is an equilibrium, the increase in time will not have a significant effect on biodiesel yield. In addition, the use of ultrasound in interesterification reactions is more on the use of time used, namely the selectivity of time to produce the perfect reaction [18, 33-35].

\subsubsection{Effects of temperature and interesterification time}

Whereas in Fig. 2(f), the most biodiesel produced is at the optimum temperature and reaction time, because the lack or excess of both can reduce the biodiesel obtained. The interaction between temperature and interesterification time has a big influence on optimizing the conversion of oil to biodiesel. The higher the reaction temperature, the more the conversion increases and also speeds up the reaction rate so as to reduce the reaction time. Because the equilibrium reaction will be achieved more quickly when high temperatures are used. However, too high a temperature and a very long time can reduce the conversion value. This is because the contact between the oil and methyl acetate is reduced due to the evaporation of the methyl acetate which will fill the reflux condenser. Casas et al. [11] have produced biodiesel from sunflower oil with potassium methoxide as a catalyst and chose $50{ }^{\circ} \mathrm{C}$ as the operating condition. In the use of a homogeneous alkaline catalyst, too high a temperature will actually reduce the yield of biodiesel because it can reduce the reactivity of the catalyst. Meanwhile, the level of cavitation effect will be lower in the use of high operating temperatures [17]. In addition, if the equilibrium reaction has been reached, the addition of reaction time will not increase the yield. But it can reduce the resulting product, considering that the interesterification reaction is a reversible reaction. Fig. 2(f) also shows that the biodiesel yield of $90 \%$ is obtained at a temperature of $48-64{ }^{\circ} \mathrm{C}$ with an interesterification time of 5-25 $\mathrm{min}$. Therefore, the use of ultrasound is more effective than conventional methods, especially in terms of reaction time [18]. So that the optimum conditions for the interesterification process were reached at a temperature of $57.84{ }^{\circ} \mathrm{C}$ and the interesterification time of $12.69 \mathrm{~min}$.

Therefore, it can be concluded that the optimal conditions for the independent variables are as follows: molar ratio of methyl acetate to oil $=18.74: 1$, catalyst concentration $=1.24 \% \mathrm{wt}$, temperature $=57.84^{\circ} \mathrm{C}$, and interesterification time $=12.69 \mathrm{~min}$. Where the predicted value for biodiesel yield of $98.64 \%$ is obtained in these conditions.

\subsection{Adequacy check of the model}

Usually, to check the experimental data analysis and the accuracy of the model, model validation is carried out with an adequacy check. A valid and highly accurate mathematical model will provide an adequate approach to the actual process. The design and residual effects for experimental data from the interesterification process can be seen in Fig. 3. Fig. 3(a) shows a plot of normal\% probability versus internally studentized residuals which is a diagnostic tool used to investigate and explain the assumptions of the system that the responses are normally distributed. This is indicated by the experimental values located linearly on a straight line so that there are no variance deviations or response transformations or problems with normality. Therefore, the normal distribution shown is very satisfying. Meanwhile, Fig. 3(b) shows the relationship between predicted versus internally studentized residuals for the interesterification process. Where for all response values, the variance remains constant. This is indicated by the distribution of points that are randomly scattered around the boundary between 0 to \pm 3 , which can be seen in the plot of Fig. 3(b). So that this model is appropriate and can be used in the study without requiring the transformation of the response variable. Meanwhile, to analyze the suitability of the model, it is indicated by the plot of run numbers versus internally studentized residuals (Fig. 3(c)). Where in Fig. 3(c), it is shown that all experimental data points are still in the range between 0 to \pm 3 . Furthermore, in Fig. 3(d), the leverage versus run number relationship is shown. Where all the experiments that have been done are still in the range of 0 to 1 for the leverage 


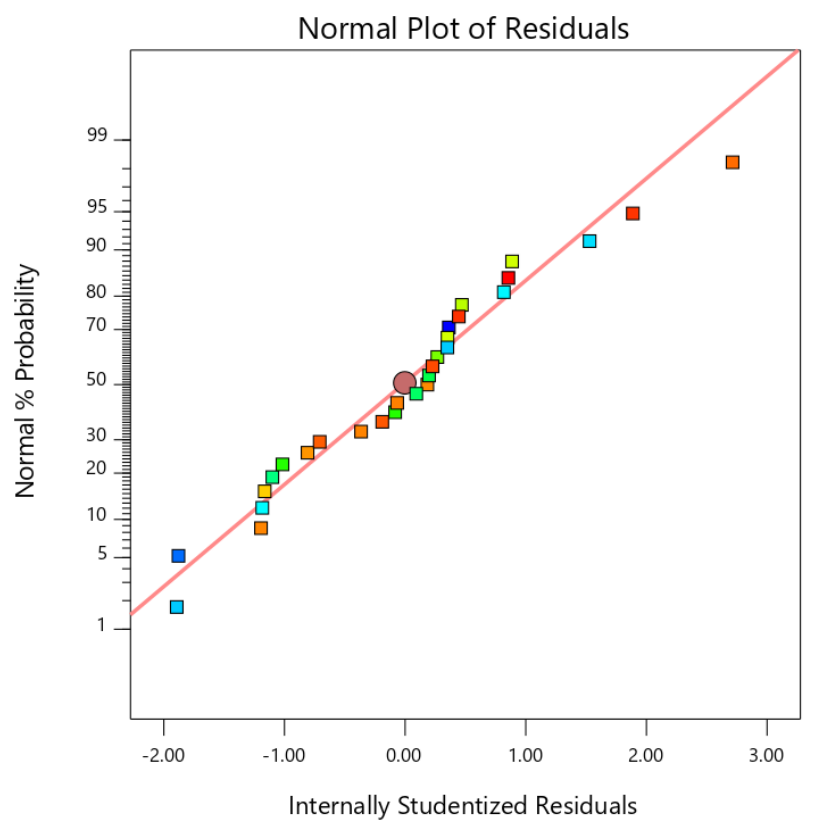

(a)

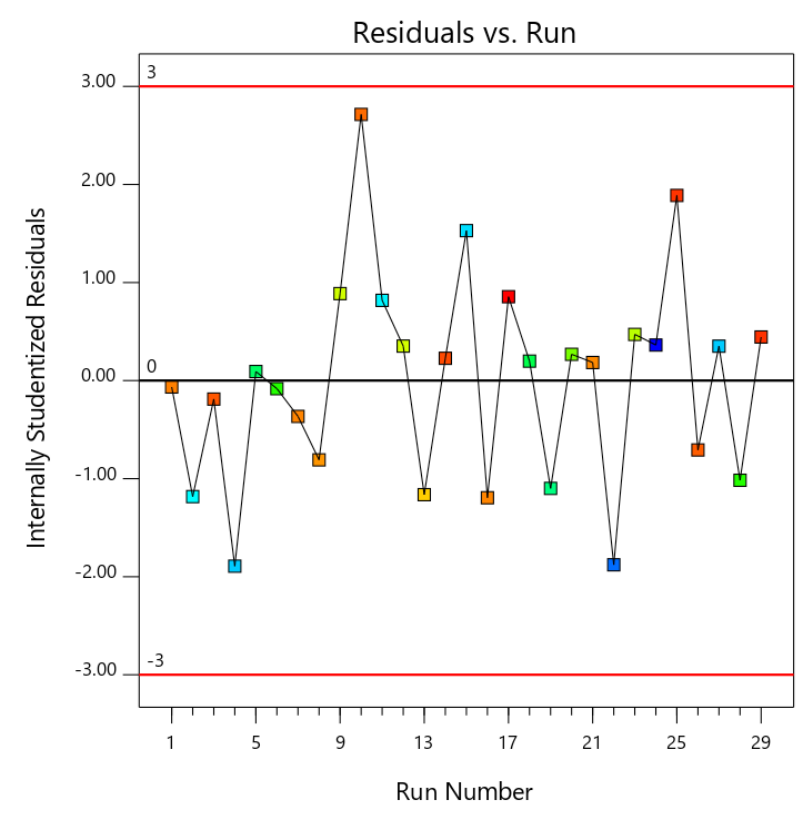

(c)

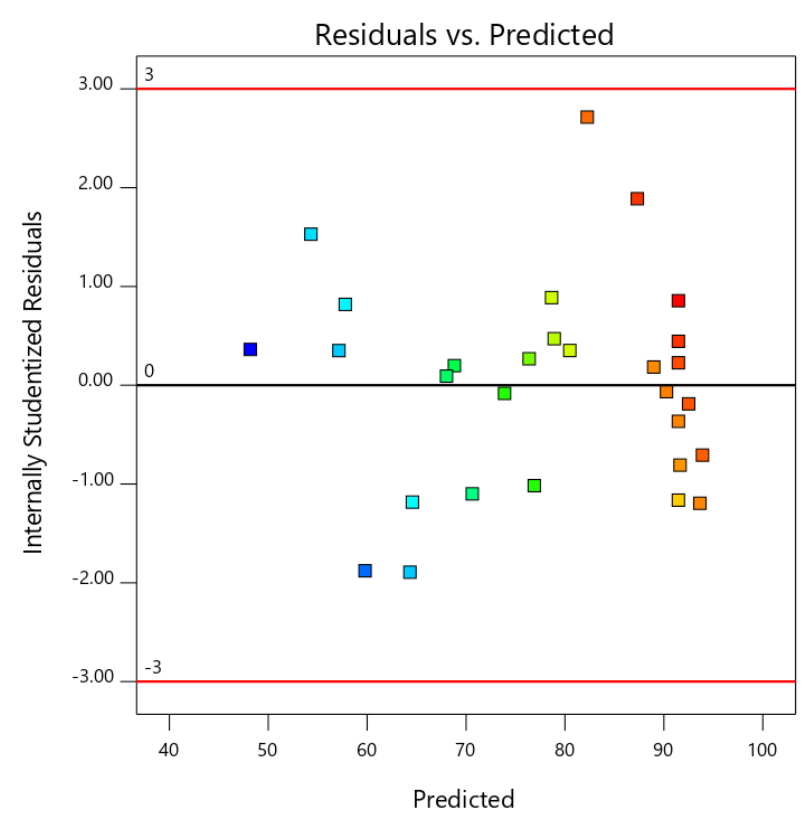

(b)

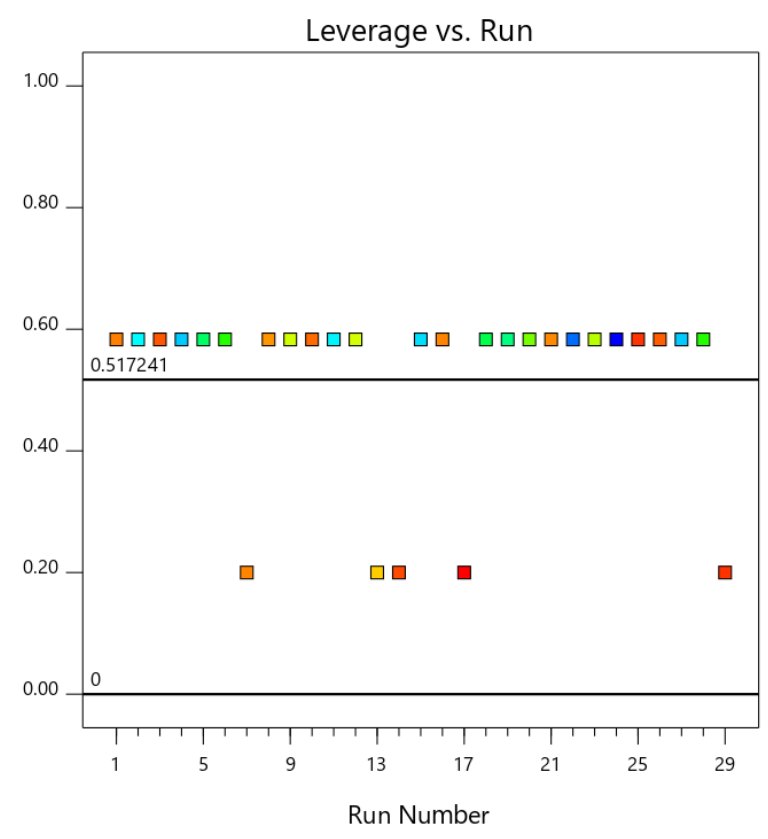

(d)

Fig. 3 Diagnostic plots for Box-Behnken model adequacy: Normal Plot of Residuals (a); Residuals vs. Predicted (b); Residuals vs. Run (c); Leverage vs. Run (d)

value. This indicates that there are no unexpected errors in the model. With satisfactory plot results in Fig. 3, it can be concluded that the empirical model is suitable for describing and optimizing the interesterification process of palm oil using ultrasound and Box-Behnken design [26-28].

\section{Conclusions}

In this study, experimental conditions were optimized by observing the effect of the interaction between the independent variables on biodiesel production using the ultrasound-assisted interesterification method and the response surface methodology (RSM). The Box-Behnken design (BBD) has been shown to be effective in estimating the effects of four independent variables; among others, the molar ratio of methyl acetate to oil, catalyst concentration, temperature, and interesterification time in biodiesel production to predict optimal operational conditions. Based on the analysis of variance (ANOVA), the 
experimental results show that the linear terms of the three independent variables (molar ratio of methyl acetate to oil, concentration of catalyst, and temperature) and all quadratic parameters have a significant effect on the response value (biodiesel yield). So that the resulting model is suitable for simulation using the Box-Behnken design (BBD). The optimal conditions for the interesterification process of palm oil using ultrasound and BBD are suggested as follows: methyl acetate to oil molar ratio of $18.74: 1$, catalyst concentration of $1.24 \% \mathrm{wt}$, temperature of $57.84{ }^{\circ} \mathrm{C}$,

\section{References}

[1] Chew, T. L., Bhatia, S. "Catalytic processes towards the production of biofuels in a palm oil and oil palm biomass-based biorefinery", Bioresource Technology, 99(17), pp. 7911-7922, 2008. https://doi.org/10.1016/j.biortech.2008.03.009

[2] Bustaman, S. "Strategi pengembangan industri biodiesel berbasis kelapa di Maluku" (Strategy for developing coconut-based biodiesel industry in Maluku), Jurnal Penelitian dan Pengembangan Pertanian, 28(2), pp. 46-53, 2009. (in Indonesian) https://doi.org/10.21082/jp3.v28n2.2009.p46

[3] Hadi, W. A. "Pemanfaatan Minyak Biji Nyamplung (Calophyllum inophyllum L) Sebagai Bahan Bakar Minyak Pengganti Solar" (Utilization of Nyamplung Seed Oil (Calophyllum inophyllum L) as a Fuel Replacement for Solar Oil), Jurnal Riset Daerah, 8(2), pp. 1044-1052, 2009. [online] Available at: https://adoc.pub/ pemanfaatan-minyak-biji-nyamplung-pemanfaatan-minyak-biji-ny.html [Accessed: 28 September 2018] (in Indonesian)

[4] Hashim, K., Tahiruddin, S., Asis, A. J. "8 - Palm and Palm Kernel Oil Production and Processing in Malaysia and Indonesia", In: Lai, O. M., Tan, C. P., Akoh, C. C. (eds.) Palm Oil: Production, Processing, Characterization, and Uses, Academic Press and AOCS Press, Urbana, Malaysia, 2012, pp. 235-250. https://doi.org/10.1016/B978-0-9818936-9-3.50011-3

[5] Varqa, S. "Essential Palm Oil Statistics", [pdf] Singapore, Singapore, Available at: www.palmoilanalytics.com [Accessed: 16 April 2018]

[6] Kusuma, H. S., Ansori, A., Wibowo, S., Bhuana, D. S., Mahfud, M. "Optimization of Transesterification Process of Biodiesel from Nyamplung (Calophyllum inophyllum Linn) using Microwave with $\mathrm{CaO}$ Catalyst", Korean Chemical Engineering Research, 56(4), pp. 435-440, 2018.

https://doi.org/10.9713/kcer.2018.56.4.435

[7] Banković-Ilić, I. B., Stamenković, O. S., Veljković, V. B. "Biodiesel production from non-edible plant oils", Renewable and Sustainable Energy Reviews, 16(6), pp. 3621-3647, 2012.

https://doi.org/10.1016/j.rser.2012.03.002

[8] Calero, J., Luna, D., Sancho, E. D., Luna, C., Bautista, F. M., Romero, A. A., Posadillo, A., Berbel, J., Verdugo-Escamilla, C. "An overview on glycerol-free processes for the production of renewable liquid biofuels, applicable in diesel engines", Renewable and Sustainable Energy Reviews, 42, pp. 1437-1452, 2015. https://doi.org/10.1016/j.rser.2014.11.007 and interesterification time of $12.69 \mathrm{~min}$, with the predicted value of biodiesel yield is $98.64 \%$. The use of ultrasound in the interesterification process can overcome the mass transfer problem due to the cavitation effect.

\section{Acknowledgement}

This research was fund supported by the Directorate General of Research and Technology of the Republic of Indonesia (RISTEK-DIKTI).

[9] Casas, A., Ruiz, J. R., Ramos, M. J., Pérez, Á. "Effects of Triacetin on Biodiesel Quality", Energy \& Fuels, 24(8), pp. 4481-4489, 2010. https://doi.org/10.1021/ef100406b

[10] Saka, S., Isayama, Y. "A new process for catalyst-free production of biodiesel using supercritical methyl acetate", Fuel, 88(7), pp. 1307-1313, 2009.

https://doi.org/10.1016/j.fuel.2008.12.028

[11] Casas, A., Ramos, M. J., Pérez, Á. "New trends in biodiesel production: Chemical interesterification of sunflower oil with methyl acetate", Biomass and Bioenergy, 35(5), pp. 1702-1709, 2011. https://doi.org/10.1016/j.biombioe.2011.01.003

[12] Campanelli, P., Banchero, M., Manna, L. "Synthesis of biodiesel from edible, non-edible and waste cooking oils via supercritical methyl acetate transesterification", Fuel, 89(12), pp. 3675-3682, 2010 .

https://oi.org/10.1016/j.fuel.2010.07.033

[13] Postaue, N., Trentini, C. P., Mello, B. T. F., Cardozo-Filho, L., Silva, C. "Continuous catalyst-free interesterification of crambe oil using methyl acetate under pressurized conditions", Energy Conversion and Management, 187, pp. 398-406, 2019. https://doi.org/10.1016/j.enconman.2019.03.046

[14] Tan, K. T., Lee, K. T., Mohamed, A. R. "Prospects of non-catalytic supercritical methyl acetate process in biodiesel production", Fuel Processing Technology, 92(10), pp. 1905-1909, 2011. https://doi.org/10.1016/j.fuproc.2011.05.009

[15] Subhedar, P. B., Gogate, P. R. "Ultrasound assisted intensification of biodiesel production using enzymatic interesterification", Ultrasonics Sonochemistry, 29, pp. 67-75, 2016. https://doi.org/10.1016/j.ultsonch.2015.09.006

[16] El Sherbiny, S. A., Refaat, A. A., El Sheltawy, S. T. "Production of biodiesel using the microwave technique", Journal of Advanced Research, 1(4), pp. 309-314, 2010. https://doi.org/10.1016/j.jare.2010.07.003

[17] Maddikeri, G. L., Pandit, A. B., Gogate, P. R. "Ultrasound assisted interesterification of waste cooking oil and methyl acetate for biodiesel and triacetin production", Fuel Processing Technology, 116, pp. 241-249, 2013. https://doi.org/10.1016/j.fuproc.2013.07.004 
[18] Medeiros, A. M., Santos, Ê. R. M., Azevedo, S. H. G., Jesus, A. A., Oliveira, H. N. M., Sousa, E. M. B. D. "Chemical interesterification of cotton oil with methyl acetate assisted by ultrasound for biodiesel production", Brazilian Journal of Chemical Engineering, 35(3), pp. 1005-1018, 2018.

https://doi.org/10.1590/0104-6632.20180353s20170001

[19] Meher, L. C., Vidya Sagar, D., Naik, S. N. "Technical aspects of biodiesel production by transesterification - a review", Renewable and Sustainable Energy Reviews, 10(3), pp. 248-268, 2006. https://doi.org/10.1016/j.rser.2004.09.002

[20] Sancheti, S. V., Gogate, P. R. "A review of engineering aspects of intensification of chemical synthesis using ultrasound", Ultrasonics Sonochemistry, 36, pp. 527-543, 2017. https://doi.org/10.1016/j.ultsonch.2016.08.009

[21] Myers, R. H., Montgomery, D. C., Anderson-Cook, C. M. "Response Surface Methodology: Process and Product Optimization Using Designed Experiments", John Wiley Sons, Inc., Hoboken, NJ, USA, 2009.

[22] Ferreira, S. L. C., Bruns, R. E., Ferreira, H. S., Matos, G. D., David, J. M., Brandão, G. C., Portugal, L. A., da Silva, E. G. P., dos Reis, P. S., Souza, A. S., dos Santos, W. N. L. "Box-Behnken design: An alternative for the optimization of analytical methods", Analytica Chimica Acta, 597(2), pp. 179-186, 2007. https://doi.org/10.1016/j.aca.2007.07.011

[23] Akkarawatkhoosith, N., Kaewchada, A., Ngamcharussrivichai, C., Jaree, A. "Biodiesel Production Via Interesterification of Palm Oil and Ethyl Acetate Using Ion-Exchange Resin in a Packed-Bed Reactor", BioEnergy Research, 13(2), pp. 542-551, 2020. https://doi.org/10.1007/s12155-019-10051-4

[24] Kashyap, S. S., Gogate, P. R., Joshi, S. M. "Ultrasound assisted synthesis of biodiesel from karanja oil by interesterification: Intensification studies and optimization using RSM", Ultrasonics Sonochemistry, 50, pp. 36-45, 2019. https://doi.org/10.1016/j.ultsonch.2018.08.019

[25] Montgomery, D. C. "Design and Analysis of Experiments", Eighth Edition, John Wiley \& Sons, Inc., Hoboken, NJ, USA, 2014.

[26] Ansori, A., Wibowo, S. A., Kusuma, H. S., Bhuana, D. S., Mahfud, M. "Production of Biodiesel from Nyamplung (Calophyllum inophyllum L.) using Microwave with CaO Catalyst from Eggshell Waste: Optimization of Transesterification Process Parameters", Open Chemistry, 17(1), pp. 1185-1197, 2019. https://doi.org/10.1515/chem-2019-0128

[27] Bahadi, M., Yusoff, M. F., Salimon, J., Derawi, D. "Optimization of response surface methodology by D-optimal design for synthesis of food-grade palm kernel based biolubricant", Industrial Crops and Products, 139, Article number: 111452, 2019. https://doi.org/10.1016/j.indcrop.2019.06.015
[28] Ahmad, A., Alkharfy, K. M., Wani, T. A., Raish, M. "Application of Box-Behnken design for ultrasonic-assisted extraction of polysaccharides from Paeonia emodi", International Journal of Biological Macromolecules, 72, pp. 990-997, 2015.

https://doi.org/10.1016/j.ijbiomac.2014.10.011

[29] Ribeiro, J. S., Celante, D., Brondani, L. N., Trojahn, D. O., Silva, C., Castilhos, F. "Synthesis of methyl esters and triacetin from macaw oil (Acrocomia aculeata) and methyl acetate over $\gamma$-alumina", Industrial Crops and Products, 124, pp. 84-90, 2018. https://doi.org/10.1016/j.indcrop.2018.07.062

[30] Hidayanti, N., Arifah, N., Jazilah, R., Suryanto, A., Mahfud, M. "Produksi Biodiesel Dari Minyak Kelapa Dengan Katalis Basa Melalui Proses Transesterifikasi Menggunakan Gelombang Mikro (Microwave)" (Production of Biodiesel from Coconut Oil with Base Catalyst through Transesterification Process Using Microwaves), Jurnal Teknik Kimia, 10(1), pp. 13-18, 2015.

[31] El-Gendy, N. Sh., Deriase, S. F., Hamdy, A., Abdallah, R. I. "Statistical optimization of biodiesel production from sunflower waste cooking oil using basic heterogeneous biocatalyst prepared from eggshells", Egyptian Journal of Petroleum, 24(1), pp. 37-48, 2015.

https://doi.org/10.1016/j.ejpe.2015.02.004

[32] Patil, P. D., Reddy, H., Muppaneni, T., Deng, S. "Biodiesel fuel production from algal lipids using supercritical methyl acetate (glycerin-free) technology", Fuel, 195, pp. 201-207, 2017. https://doi.org/10.1016/j.fuel.2016.12.060

[33] Kashyap, S. S., Gogate, P. R., Joshi, S. M. "Ultrasound assisted intensified production of biodiesel from sustainable source as karanja oil using interesterification based on heterogeneous catalyst ( $\gamma$-alumina)", Chemical Engineering and Processing - Process Intensification, 136, pp. 11-16, 2019. https://doi.org/10.1016/j.cep.2018.12.006

[34] Casas, A., Ramos, M. J., Pérez, Á. "Kinetics of chemical interesterification of sunflower oil with methyl acetate for biodiesel and triacetin production", Chemical Engineering Journal, 171(3), pp. 1324-1332, 2011. https://doi.org/10.1016/j.cej.2011.05.037

[35] Narváez, P. C., Rincón, S. M., Sánchez, F. J. "Kinetics of Palm Oil Methanolysis", Journal of the American Oil Chemists' Society, 84(10), pp. 971-977, 2007. https://doi.org/10.1007/s11746-007-1120-y 